University of Nebraska - Lincoln

DigitalCommons@University of Nebraska - Lincoln

Faculty Publications: Agricultural Leadership, Education \& Communication Department
Agricultural Leadership, Education \& Communication Department

4-2-1995

\title{
A MODEL FOR THE EVALUATION AND REWARD OF TEACHING IN AGRICULTURAL EDUCATION
}

\author{
Leverne A. Barrett \\ University of Nebraska - Lincoln, Ibarrett@unlnotes.unl.edu \\ Elizabeth Banset \\ University of Nebraska-Lincoln, ebanset1@unl.edu \\ Osmund Gilbertson \\ University of Nebraska - Lincoln, ogilbertson2@unl.edu
}

Follow this and additional works at: https://digitalcommons.unl.edu/aglecfacpub

Part of the Other Public Affairs, Public Policy and Public Administration Commons

Barrett, Leverne A.; Banset, Elizabeth; and Gilbertson, Osmund, "A MODEL FOR THE EVALUATION AND REWARD OF TEACHING IN AGRICULTURAL EDUCATION" (1995). Faculty Publications: Agricultural Leadership, Education \& Communication Department. 6.

https://digitalcommons.unl.edu/aglecfacpub/6

This Article is brought to you for free and open access by the Agricultural Leadership, Education \& Communication Department at DigitalCommons@University of Nebraska - Lincoln. It has been accepted for inclusion in Faculty Publications: Agricultural Leadership, Education \& Communication Department by an authorized administrator of DigitalCommons@University of Nebraska - Lincoln. 


\title{
A MODEL FOR THE EVALUATION AND REWARD OF TEACHING IN AGRICULTURAL EDUCATION
}

\author{
Leverne A. Barrett, Professor \\ Elizabeth Banset, Assistant Professor \\ Osmund Gilbertson, Professor \\ University of Nebraska-Lincoln
}

\begin{abstract}
In 1986, the Fund for the Improvement of Postsecondary Education (FIPSE), U.S. Department of Education, issued its first call for innovative approaches to solve the problem of reward for teaching in American universities. The FIPSE Board of Directors and staff recognized that the greatest disparity in the postsecondary reward system occurred in research-oriented universities where research garnered more rewards than teaching. They concluded that if teaching in American universities was going to improve, the reward structures in higher education needed to change. This article describes a plan designed to evaluate and reward teaching in the Department of Agricultural Leadership, Education, and Communication (AgLEC) at the University of Nebraska-Lincoln (UNL). It begins with background information about the FIPSE-sponsored project out of which the evaluation and reward plan grew, traces the development of the AgLEC plan, describes each component of the plan, and assesses the effectiveness of the plan after three years in place.
\end{abstract}

In response to the 1987 FIPSE call for proposals, a small group of faculty at UNL developed a plan to address two facets of the reward issue: faculty evaluation and faculty development. It was an ambitious plan involving faculty and administrators from two diverse academic cultures -- The College of Agricultural Sciences and Natural Resources (CASNR) and the College of Arts \& Sciences (A\&S). The plan's originators hypothesized that if such an effort to adjust the reward system in two diverse cultures were successful, the plan would be transferable to other institutions.

The FIPSE Board rejected the proposal on the grounds that the reward system for teaching in research-oriented universities could not be adequately corrected. However, they did fund a planning grant for the purpose of refining the UNL proposal. As part of the planning grant, a survey of UNL faculty was conducted to determine the status of the reward system (McClain, 1987). The McClain study clearly showed that faculty did not believe teaching was adequately rewarded with merit, promotion, and tenure. The results of the study were shared with university administrators; a few rejected the findings, but most agreed something needed to be done to correct the problem of disparity in reward for research vs. teaching activities. As a result, a second proposal was submitted to FIPSE, which, after two tries, was finally funded for three years. The proposed project was titled "From Regard to Reward: Rewarding Teaching at Research-Oriented Universities."

Two departments in CASNR and two in A\&S were solicited to participate in the first year. The departments of Agricultural Education (which later merged with the Department of Agricultural Communications to become the Department of Agricultural Leadership, Education, and Communication [AgLEC]), Agronomy, Psychology, and English agreed to be the pilot departments. Each department was asked to develop a model plan for the evaluation and reward of teaching consistent with its values and norms. What follows is a description of the development and implementation of the plan in the AgLEC 
department.

\section{Development of the Agricultural Leadership, Education, and Communication Plan}

To establish a need to change the reward system in Agricultural Education, a survey of all departmental faculty was conducted. In brief, the results showed that faculty perceived that the existing system to evaluate and reward effective teaching -- based on student evaluations, the number of students advised, involvement on committees, and hearsay -- was inadequate and needed changing, because no objective system of measurement had yet been devised.

During an early faculty retreat, a plan to correct the problem of evaluation and reward was developed, although there was considerable disagreement over the content of the plan and how specific items would be weighted. Further refinements occurred when the Agricultural Education Department merged with Agricultural Communications and the combined faculty reassessed the plan's content and procedures to suit the needs of the new department. The refinement process was relatively painless, since both departments had independently developed remarkably similar plans for evaluating and rewarding teaching.

\section{Components of the Teaching Improvement Plan}

The AgLEC teaching evaluation plan links improvement in teaching to reward in the form of annual merit raises and promotion and tenure decisions. The plan was based on the premise that rewards for effective teaching could not be devised on the evidence of student evaluations alone. The plan that eventually developed calls for all faculty who teach at least one 3-credit hour course for the department, regardless of status (part-time, adjunct, tenure-track or tenured), to prepare a portfolio documenting teaching successes in nine separate areas (see next section for a list and description of these areas). Portfolios are submitted annually to the Peer Teaching Evaluation Committee, a group of four faculty members elected by their peers within the department, who review each portfolio and award points for documented activities in each area. (Note: the committee reviews at least 13 portfolios each year, and as many as 17 , depending on the number of part-time faculty teaching for the department).

Evaluation of portfolios is based on a set of pre-defined criteria approved by the entire faculty and applied on a case-by-case basis. The committee then prepares a summary report for individual faculty members with suggestions for improving teaching in the next year, forwards a copy of the summary to the department head (who uses that information to help guide decisions about merit raise awards), and offers to meet individually with faculty members to further discuss the evaluation and suggested improvements.

\section{The Portfolio}

Faculty in the AGLEC Department gather evidence of effective teaching in a portfolio divided into the nine separate areas listed here and described in more detail below:

1. Student evaluation of teaching

2. Written faculty response to student evaluations

3. Annual and long-term objectives for teaching

4. Creative/scholarly activities in teaching and learning

5. Professional development in teaching and learning

6. Course outlines, objectives, and evaluation policies

7. Advising

8. Classroom observation

9. Peer review

Student Evaluation of Teaching

Each faculty member is required to administer 
the college-wide student evaluation form (Course/Instructor Evaluation Questionnaire [CIEQ] developed by Aleamoni [1975]). It includes standard questions that rate the instructor and the course, as well as some open-ended questions for student comments. For purposes of the AgLEC plan for rewarding effective teaching, faculty are required to include in their portfolios only the statistical mean for the "instructor" subscale of the evaluation for each course/section taught each semester.

Student evaluations account for $25 \%$ of the total portfolio scoring (25 points). Full points are awarded if the mean score for "instructor" on the CIEQ is 3.6 or above (on a scale of 4.0). The point award is adjusted downward if the mean score average falls below 3.6. The 3.6 average was chosen to ensure a greater distribution of scores from the mean.

\section{Written Faculty Response to Student Evaluations}

Each faculty member answers in short paragraph form these four questions: 1) What are the most significant positive student comments (from the CIEQ evaluation)? 2) What are the most significant student concerns/criticism gleaned from the student evaluation open comments? 3) What are your professional reactions to the student observations? and 4) Describe the key points of an action plan to address student concerns/criticisms for the improvement of teaching effectiveness during the next year.

Faculty response to student evaluations accounts for $10 \%$ of the total portfolio scoring (10 points). The response must identify significant student concerns and propose a specific plan for dealing with them. The point award is adjusted downward if the response is vague or incomplete.

Table 1. Creative/Scholarly Activity in Teaching
Annual and Long-Term Objectives for Teaching

Faculty include in their portfolios supporting evidence relating specifically to achievement of, or progress toward, short-term and long-term goals related to reaching. The point award is adjusted downward if goals are vague, incomplete, or not specifically related to teaching.

The description of teaching objectives accounts for $5 \%$ of the portfolio scoring (5 points). Goals from previous year must be listed, along with an explanation of how they were achieved; objectives for the next year must be specifically related to teaching and clearly measurable in terms of outcomes; and long-term goals related to teaching must be listed. The point award is adjusted downward if goals are vague, incomplete or not specifically related to teaching.

\section{Creative/Scholarly Activity in Teaching and Learning}

This section of the teaching portfolio has undergone the most revision, especially in regard to the weight or value placed on activities as the department continues to upgrade its plan for rewarding teaching. Faculty are encouraged to maintain an ongoing record of their scholarly contributions through publications and presentations. The list in Table 1is provided to help faculty identify creative and scholarly activities they have engaged in over the past year, but individuals may include activities not listed. The list of creative activities in teaching is intentionally diverse to represent the variety of expertise among the department's faculty.

Participation in creative/scholarly activities in teaching and learning accounts for $15 \%$ of the total portfolio scoring. Points are awarded according to the list in the guidelines in the teaching evaluation 
Five Year Listing:

Refereed Teaching Publication 5

Non-Refereed Teaching Publication 2

$\begin{array}{ll}\text { Instructional Material (statewide) } & 10\end{array}$

Published Book $\quad 10$

Chapter in Book 5

Monographs $\quad 5$

Proceedings $\quad 2$

Abstracts 1

Writer's Update 1

Published Book Review 1 1-2

Bibliographies $\quad .5-2$

Current Year Listing:

Invited Paper/Symposium (national) $\quad 5$

Invited Paper/Symposium (regional) $\quad 4$

Invited Paper/Symposium (state) 3

Refereed Paper (national)

Refereed Paper (regional) 4

Development of New Course 3 per credit

Major Modification of Course 1 per credit

Grants and Proposals (per $\$ 1000$ of total budget) $\quad .2$ (New)

Grants and Proposals (per $\$ 1,000$ of total budget) .1 (Renewal)

External Grant Proposal 1 - 5

Classroom Research Project 1 - 3

Special Curriculum Project $1-4$

Workshop Conducted $1-3$

Workshop Facilitated $\quad .5$

packet, up to a maximum of 15 points. Scores in this area are adjusted based on the percentage of an individual's appointment that applies to teaching (e.g., if someone has a 50\% teaching appointment, the maximum he/she would be expected to earn in this area is 7.5 points. The final basis would be adjusted accordingly).

Professional Development in Teaching and Learning

Each faculty member is encouraged to maintain a record of attendance at and participation in professional development activities in teaching.

The nature of professional development activities will vary from faculty member to faculty member, depending on his or her area of expertise. The list in Table 2 is designed to help faculty identify professional development activities.

Professional development in teaching and learning accounts for $15 \%$ of the total portfolio scoring. Points are awarded according to the list in the guidelines in the teaching evaluation packet, up 
to a maximum of 15 . Scores in this area are adjusted based on the percentage of an individual's appointment that applies to teaching. For example, if someone has a $50 \%$ teaching appointment, the maximum he/she would be expected to earn in this area is 7.5 points. The final basis would be adjusted accordingly.

Table 2. Professional Development in Teaching

$\begin{array}{lr}\text { Professional Meeting (international) } & 4 \\ \text { Professional Meeting (national) } & 3 \\ \text { Professional Meeting (regional) } & 2 \\ \text { Professional Meeting (state) } & 1 \\ \text { Service on Professional Committee (national) } & 3 \\ \text { Service on Professional Committee (regional) } & 2 \\ \text { Service on Professional Committee (state) } & 1 \\ \text { Undergoing the Peer Review Process } & 3 \\ \text { Sabbatical/Faculty Development Leave } & 5 \\ \text { Travel/Observation for Improvement } & 3 \\ \text { Seeking Professional Development Assistance } & 2 \\ \text { Professional Skill Development (e.g., language, teaching skills, etc.) } & 2 \\ \text { Refereeing for Journals } & 1 \\ \text { Editorial Consulting (book) } & 2 \\ \text { Attending On-Campus Workshops } & 1 \\ \text { Coker Observations of Other Faculty } & 1\end{array}$

\section{Course Outlines, Objectives, Policies}

Faculty members must include in the portfolio copies of materials distributed to students outlining the course schedule, course objectives, and evaluation policies. The evaluation committee reviews them for clarity and completeness.

This section of the portfolio accounts for $10 \%$ of the portfolio scoring (10 points). The description of objectives, schedule, and evaluation policies must be clear and easy for students to use, and course activities must appear to meet the objectives stated. The point award is adjusted downward if outlines, objectives, and policies are vague or incomplete.

\section{Student Advising}

Faculty who have student advising responsibilities as a component of the teaching appointment are required to submit a statement summarizing advising activities and reflecting on ways in which advising could be improved the next year. Only faculty with advising responsibilities add this section to the portfolio; for them, this accounts for $5 \%$ of the portfolio scoring (5 points). The statement must clearly summarize advising activities and reflect ways to improve advising effectiveness. In addition, advising responsibilities must be appropriate to the individual.

Inclusion of advising as a category in the teaching portfolio has generated some concern because every faculty member does not have 
advising responsibilities. Those who do not are exempt from reporting in this area; those who do advise, however, could be penalized if they fail to report advising or they omit the reflective statement on strategies for improving advising.

\section{Classroom Observation}

A minimum of two classroom observations per semester are required for all non-tenured faculty and at least one observation is required for tenured faculty. Observers are faculty peers who have been trained to use the Classroom Observations Keyed for Effectiveness Research (COKER) instrument. The COKER (Coker, 1988) is a low inference-sign instrument for collecting data about teacher and student activity. At least six data sheets are collected during each hour of observation. Data sheets are scanned and analyzed by computer to generate a profile of effectiveness for agreed upon teaching effectiveness criteria. Each criterion is placed on a fixed mean of 50 for comparison with other faculty in the department. Faculty members must submit a copy of the COKER printout as part of the portfolio.

The classroom observation report accounts for $10 \%$ of the total portfolio scoring (10 points). COKER scores in all competencies must fall above 40 (in terms of the department average) to receive the full 10 points. The point award is adjusted downward by one point for each score that falls below 40; it is adjusted upward for each score above 60 (not to exceed the maximum of 10 points).

\section{Peer Review}

Peer review occurs in two phases. Each nontenured faculty member is required to meet periodically with an individual, self-appointed peer review committee to examine his or her teaching. The purpose of this review is to help non-tenured faculty improve and develop their teaching. The second peer review phase consists of evaluation of the entire teaching portfolio by the group of four elected faculty who serve as the Peer Teaching Evaluation Committee. Their charge is to evaluate each faculty member's teaching portfolio, assign a score, and provide written comments and recommendations for improvement. Non-tenured faculty members who are required to participate in peer review must submit as part of their portfolio a letter from their peer review group indicating that the group has met and identifying review activities completed.

Peer review accounts for $5 \%$ of the total portfolio scoring (5 points) and applies only to nontenured faculty in tenure-leading positions. Evidence of peer review must be presented in the form of a letter from the peer review committee.

\section{Scoring and Reporting Methods}

Evaluation is based on a total of 100 points. The 100 point basis is adjusted in each case, discounting points in areas that do not apply to an individual's situation. The final score is computed by dividing the number of points earned by the basis. For example, an instructor who does not have advising responsibilities would be eligible for a maximum of 95 points, rather than 100, and the final score would be computed by dividing points earned by 95 , not 100 .

The committee's scores and open-ended summary responses in each category are passed along to individual faculty members and to the department head, who uses the information to make decisions about merit raises. Faculty are invited to make appointments with the Peer Teaching Evaluation Committee to further discuss the portfolio and suggestions for improving teaching.

\section{Results/Conclusions}

Most of the skepticism about whether the plan would work occurred during the first year of the merged department. Some opposition developed to the classroom observations using the COKER instrument. Faculty were not accustomed to having 
their teaching practices scrutinized by trained observers and they did not understand how the scores on the COKER instrument were derived. Now that the plan has been in use for three years, faculty satisfaction with the overall plan to evaluate and reward teaching has increased.

This reduction in opposition is due to several factors: 1) faculty play a major role in improving the plan each year; 2) confidence in the peer review process has grown (at the level of both the individual peer review committee and the department's Peer Teaching Evaluation Committee); and 3) faculty clearly understand the basis upon which their teaching appointment is judged.

Other results are evident:

1. Every faculty member submits a teaching portfolio for peer review.

2. The quality of the portfolios has improved in the three years the plan has been in effect.

3. Faculty are participating in a larger number and variety of teaching improvement activities, such as the departmental teaching circle and the college-wide teaching community.

4. Teaching objectives identified by individual faculty members more accurately reflect specific teaching improvement methods.

5. Reflective analysis of student criticisms of teaching is evident and becoming more insightful.

6. Faculty show more interest in talking about and sharing ideas about teaching.

7. Teaching has achieved a rightful place in merit, promotion/tenure considerations.

8. The department takes pride in being recognized by the university community as an outstanding teaching department for the past three years.

\section{Recommendations}

Based on our experiences developing a plan for evaluating and rewarding teaching in an agricultural education department, we offer these suggestions to others who may be undertaking a similar task:

1. When choosing to realign the reward/evaluation system of a department, choose faculty leaders who have the respect of others and are willing to take risks.

2. When evaluation criteria have been selected in each category, assign weights or point values (even if you have a hard time agreeing what they should be, or someone else will).

3. Allow significant amounts of time to develop strategies; retreats can be very useful.

4. Attempt to gain consensus on the definition of scholarship in teaching.

5. Define effective teaching in the context of your department.

6. Use the new system on a trial basis.

7. Assess and re-evaluate the process, especially during the first few years.

\section{References}

Aleamoni, L. (1975). Arizona course/instructor evaluation questionnaire (CIEQ). Tucson: University of Arizona, Office of Instructional Research and Development.

Department of Agricultural Leadership, Education and Communication (1993). Procedures for evaluating the teaching effectiveness of faculty. Unpublished report, University of NebraskaLincoln, Lincoln, NE. 
McClain, C. (1987). Study to determine the perceptions of faculty at the University of Nebraska concerning teaching, promotion and tenure. Unpublished report, Teaching and Learning Center, University of Nebraska-Lincoln, NE.

Coker, H. \& Coker, J. (1988). Classroom observations keyed for effectiveness research. Atlanta: University of Georgia.

Barrett, L., Narveson, R., et.al. (1994). From regard to reward: Improving teaching at a researchoriented university. Department plans: documentation, evaluation, and reward. Lincoln,
NE: University of Nebraska-Lincoln.

Barrett, L., Narveson, R., et.al. (1992). From regard to reward: Improving teaching at a research oriented-university. Lincoln, NE: University of Nebraska-Lincoln.

Wright, D. (1992). From Regard to Reward: Improving teaching at a research-oriented university. How to proceed: from department to college to institution. Lincoln, NE: University of Nebraska-Lincoln. 